\title{
СПРОЩЕНА МАТЕМАТИЧНА МОДЕЛЬ ПРОЦЕСУ ГРАФІТУВАННЯ ВУГЛЕЦЕВИХ ЕЛЕКТРОДІВ
}

Simplified mathematical model of carbon electrode graphitization.

\author{
Zhuchenko O.A., PhD, Associate Professor ${ }^{1}$, Bevziyk L.L., master student ${ }^{2}$ \\ ${ }^{1,2}$ Національний технічний університет України «Київський політехнічний інститут імені Ігоря Сікорського», м. Київ \\ E-mail: ${ }^{1}$ azhuch@ukr.net \\ ${ }^{1}$ ORCID: 0000-0001-5611-6529
}

Copyright (C 2014 by author and the journal "Automation technological and business - processes". This work is licensed under the Creative Commons Attribution International License (CC BY). http://creativecommons.org/licenses/by/4.0/

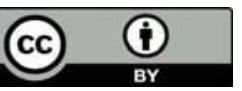

ONAFT

Open Access

\begin{abstract}
Аннотация
Виробництво вуглецевих електродів характеризується значною ресурсо- та енергосмністю, тому актуальною с задача підвищення ефективності даного виробництва шляхом впровадження оптимальних режимів роботи його складових технологічних процесів. Розроблена та досліджена спрощена математична модель процесу графітування вуглецевих електродів, яка відрізнясться від відомих моделей практично нульовим часом ії розрахунку. Побудована спрощена математична модель надає можливість підвищити ефективність дослідження температурного режиму процесу графітування вуглецевих електродів за рахунок скорочення часу дослідження, визначати температури у будь-якій точці процесу. Дослідження точності спрощених моделей проводилось шляхом порівняння значень температур, розрахованих за цими моделями, 3 температурами, обчисленими за початковою складною моделлю, які у даному випадку розглядаються як експериментальні дані. У результаті спрощена математична модель може бути використана для синтезу системи керування процесом, а також у складі системи керування реального часу.
\end{abstract}

Ключевые слова

Графітування, вуглецеві електроди, математична модель, енергозбереження.

\section{Abstract}

Production of carbon electrodes characterized by considerable resource and energy consumption, so important is the task of improving the efficiency of production through the introduction of optimal modes of its component processes. Developed and studied a simplified mathematical model of carbon electrodes graphitization, which differs from the known models almost zero time to calculate it. Constructed simplified mathematical model allows increasing effectiveness research process temperature control graphitization carbon electrodes by reducing the time a study to determine the temperature at any point in the process. Research conducted simplified models accuracy by comparing the temperature values calculated by these models, with temperatures calculated for the original complex model, which in this case is regarded as experimental data. As a result, a simplified mathematical model can be used for the synthesis of process control systems, as well as in the control system real time.

Key words

Graphitization, carbon electrodes, mathematical model, energy.

\section{Введение}

Споживачами вуглецевих виробів є різні галузі промисловості, в яких виробництво пов'язане 3 необхідністю використання електротермічних технологічних процесів. Зокрема, до таких виробництв відносяться підприємства чорної та кольорової металургії, машинобудування, хімічної промисловості та інші.

Особливе місце серед електродної продукції посідає графітована електродна продукція, перш за все через високі показники якості, такі, як висока міцність, теплопровідність, низький питомий опір тощо. 
Процес виготовлення графітованої електродної продукції, хоч і не складний, але надзвичайно енергоємний, а відтак і надзвичайно затратний. Ключовим апаратом у всій технологічній лінії виготовлення графітованої електродної продукції $є$ піч графітування - піч Ачесона. Піч Ачесона $є$ електропіччю, із надзвичайно високим споживанням електроенергії і хоча б незначне зменшення питомої витрати електроенергії призвело б до суттєвої економії та здешевлення готової продукції.

Саме тому актуальною є задача підвищення ефективності даного процесу шляхом впровадження оптимальних режимів його роботи. Розв'язання даної задачі передбачає проведення експериментальних досліджень процесу графітування, за результатами яких має бути створена і впроваджена система оптимального керування ним.

Проведення експериментальних досліджень з метою створення системи оптимального керування процесом графітування на діючому технологічному обладнанні практично неможливе за декількома причинами. До головних 3 них відносяться додаткові ресурсо- та енерговитрати, ймовірність виникнення аварійної ситуації, значні економічні втрати у зв’язку з ймовірним виробництвом бракованої продукції та інші.

Фактично єдиною альтернативою у цій ситуації $€$ використання методу математичного моделювання технологічних процесів [1, 2], який дозволяє при наявності адекватної математичної моделі процесу проводити експериментальні дослідження практично у необмеженому діапазоні зміни технологічних параметрів, що дає можливість досконально дослідити технологічний процес.

Математичному моделюванню процесу графітування присвячена значна кількість наукових праць [3-7]. Враховуючи, що процес графітування як об'єкт математичного моделювання є об'єктом 3 розподіленими параметрами, то у даних роботах, як правило, математична модель являє собою систему нелінійних нестаціонарних рівнянь у частинних похідних. Час розрахунку такої моделі на сучасному стаціонарному комп'ютері складає декілька годин. Така тривалість розрахунку, по-перше, суттєво ускладнює безпосередньо дослідження процесу графітування вуглецевих виробів i, по-друге, робить неможливим використання такої моделі у системах керування реального часу.

Названі обставини висувають нагальну задачу спрощення початкової складної моделі, створюючи математичну модель процесу графітування, яка потребує невеликого часу розрахунку та задовольняє вимогам щодо ії точності по відношенню до початкової моделі.

Аналіз існуючих методів спрощення математичної моделі

У наш час розроблений цілий ряд методів побудови спрощених математичних моделей об'єктів з розподіленими параметрами ОРП [3, 8-14]. Всі вони можуть бути умовно поділені на дві основні групи згідно «предмету апроксимації» [15].

Перша група утворюється різними способами спрощеного представлення самих вихідних диференціальних рівнянь об'єкта, наступний розв'язок яких відомими методами дозволяє отримати задовільні за точністю у визначених конкретних умовах опису властивостей ОРП у порівняно простому вигляді.

Методи другої групи базуються на наближеному представленні (як правило, у типовій для об'єктів 3 зосередженими параметрами (ОЗП) формі відповідних передатних функцій) точних розв’язків рівнянь у частинних похідних, які моделюють поведінку ОРП.

Можливе послідовне застосування до однієї й тієї самої ОРП різних методів апроксимації, що дозволяють, наприклад, спочатку перейти до спрощеного, що допускає точний аналітичний розв' язок, рівнянню об' єкта, для якого потім знайти дробово-раціональне наближення його передатної функції, що визначає результуюче наближення опису вихідної моделі об’ єкта у вигляді типових моделей ОЗП.

Одним з найбільш ефективних методів побудови спрощеної математичної моделі ОРП є метод розділення змінних (метод Фур'є) [1, 10,11], що передбачає представлення функції декількох змінних (часу і просторових координат) у формі нескінченного ряду, кожний член якого являє собою добуток двох функцій однієї змінної - часу та просторової координати

$$
T(\xi, t)=\sum_{i=1}^{\infty} a_{i}(t) \varphi_{i}(\xi),
$$

де апріорі невідомі функції $a_{i}(t)$ та $\varphi_{i}(\xi)$ мають бути вибрані таким чином, щоб керована змінна $T(\xi, t)$ задовольняла граничним умовам задачі.

На практиці ряд (1) обмежують $n$ членами

$$
\hat{T}(\xi, t)=\sum_{i=1}^{n} a_{i}(t) \varphi_{i}(\xi)
$$

і тоді задача апроксимації зводиться до визначення невідомих функцій $a_{i}(t)$ та $\varphi_{i}(\xi)$ із умови мінімізації певного функціонала похибки апроксимації та дослідженню збіжності $\hat{T}(\xi, t)$ до $T(\xi, t)$ при $n \rightarrow \infty$.

Постановка задачі

На рис.1 схематично зображена завантажена піч графітування. Футеровка печі виконується 3 шамотної цегли і складається 3 поду 1, торцевих стінок 2 та бічних стінок (на рисунку не вказані). Часто бічні стінки виконують 
розбірними, як правило із жаротривкого бетону. Стаціонарні бічні стінки та под, як правило, містять канали 3 для повітряного охолодження футеровки під час кампанії графітування.

В торцеві стінки печі вмонтовані струмопідвідні електроди 4, до яких із зовнішньої сторони під’єднуються пічні шини. Для запобігання окиснення електродів під час експлуатації, їх герметизують в місцях встановлення. Для цього в торцевих стінках передбачені порожнини 5, що щільно заповнені дрібнодисперсним графітом. Внутрішню поверхню торцевої стіни захищають за допомогою захисного екрану 6 із вуглецевих плит або вуглецевої маси товщиною 80..100мм. Верхню поверхню торцевих стінок захищають бетонними плитами 7.

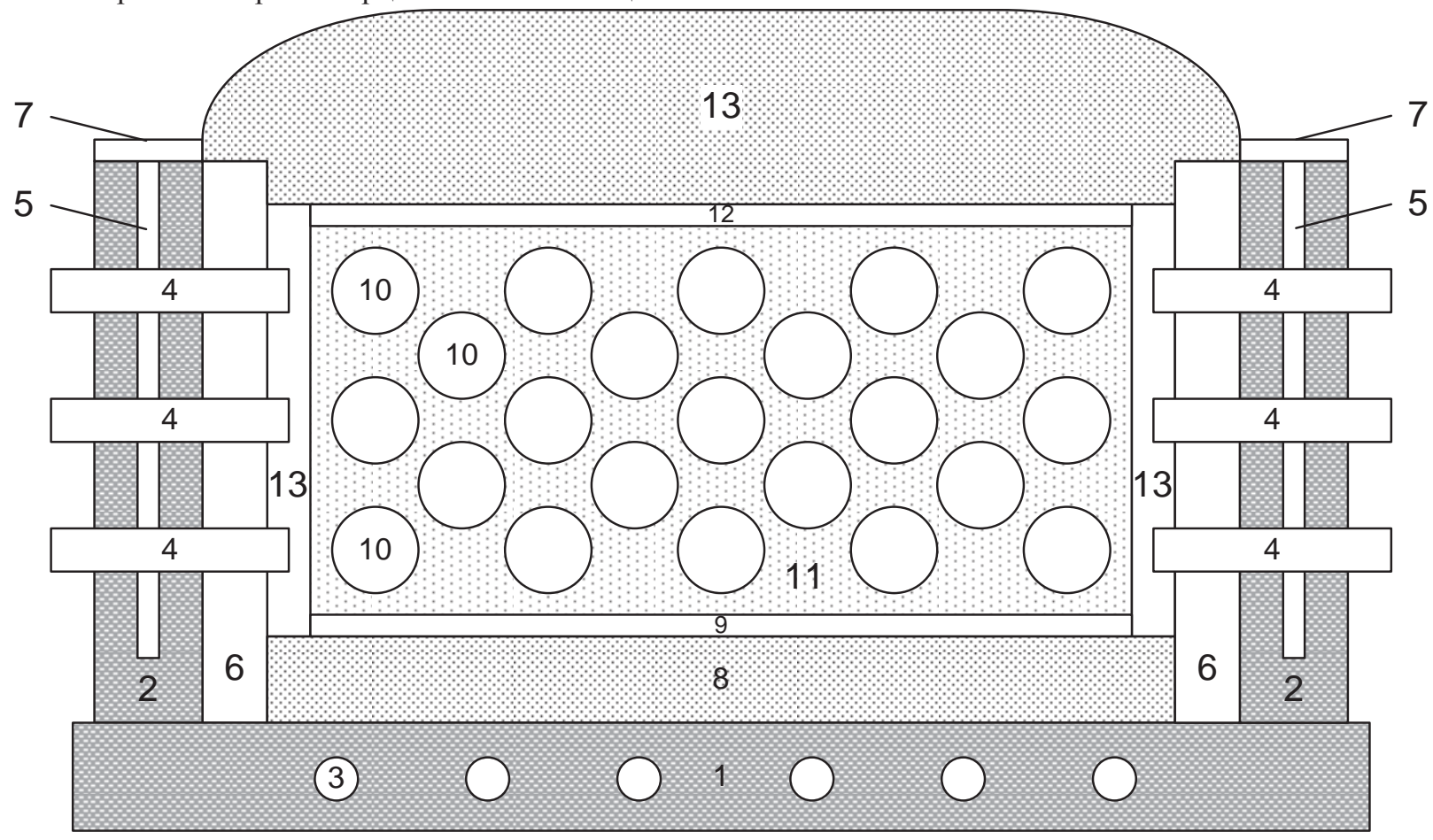

Рис.1 - Схематичне зображення завантаження печі Ачесона

Після дрібного ремонту піч графітування завантажують для наступної кампанії.

Для цього под печі вкривають шаром теплоізоляційної шихти 8 завтовшки 500..900мм. теплоізоляційна шихта складається 3 гранульованого коксу фракції 0..10мм, піску та деревної тирси. Значну частину теплоізоляції може складати зворотна шихта.

Формування керну печі відбувається таким чином: бічні та торцеві стінки відгороджують щитами так, щоб між ними та стінками існував вільний простір, потім на шар теплоізоляції 8 насипають шар металургійного коксу 9 фракції 10..25мм; після цього перпендикулярно до осі печі завантажується перший ряд електродних заготовок 10, а простір між самими заготовками заповнюється керновою пересипкою 11; за таким самим принципом утворюють наступні шари із електродними заготовками. Зазвичай пересипку виготовляють із гранульованого металургійного коксу фракції 10..25мм, або дрібнішої, за графітування дрібної електродної продукції. Верх керну вкривають насипом iз графітованого коксу 12. Коли керн сформовано, простір між щитами та бічними стінками заповнюють теплоізоляційною шихтою (на рисунку не вказано), а простір між щитами і торцевими стінками наповнюють графітованим коксом 13, після чого щити виймають. Наступним кроком є формування шару верхньої теплоізоляції 14 товщиною 500..800мм. [4, 6].

За свідченням багатьох авторів [4-7, 16, 17] температурний режим роботи печі графітування є визначальним, тобто таким, від якого фактично залежать техніко-економічні показники процесу графітування. Тому важливо, щоб математична модель процесу давала змогу розраховувати саме температурні поля процесу графітування у залежності від підведеної електричної потужності на різних режимах її роботи.

У подальшому спрощені математичні моделі будуються та досліджуються для чотирьох просторових точок, які найбільш суттєво впливають на ступінь графітування електродних заготовок , а саме: 1 - центр середньої заготовки, 2 - периферія середньої заготовки, 3 - центр пересипки середньої заготовки, 4 - периферія пересипки середньої заготовки.

Як керування використовується потужність електричного струму, що підводиться до печі графітування. Розрахункові значення температур отримані при максимальній силі струму 1000 кА та максимальній напрузі у 300 В.

Як початкова складна математична модель процесу графітування вуглецевих виробів у даній статті використана модель [16], а як метод спрощення моделі - метод, запропонований у [18], оснований на методі Фур' $€$. 
Таким чином, метою даної статті є побудова та дослідження спрощеної математичної моделі процесу графітування вуглецевих виробів, яка б потребувала невеликого часу розрахунку та відповідала вимогам щодо іiі точності по відношенню до початкової математичної моделі.

\section{Методика дослідження}

Спрощення математичної моделі процесу графітування вуглецевих виробів полягає у апроксимації результатів розрахунків за початковою складною моделлю менш складною моделлю (моделлю із меншою кількістю рівнянь). Таким чином, для проведення апроксимації спочатку треба розрахувати змінні $T(\xi, t)$ (зразки) при різних значеннях керування $u(t)$ за допомогою початкової математичної моделі.

Отримані у результаті розрахунків зразки представлені у вигляді матриці

$$
T_{\text {зраз }}(k):=\left[\begin{array}{cccc}
\tilde{T}\left(\xi_{1}, t_{1}\right) & \tilde{T}\left(\xi_{1}, t_{2}\right) & \ldots & \tilde{T}\left(\xi_{1}, t_{K}\right) \\
\tilde{T}\left(\xi_{2}, t_{1}\right) & \tilde{T}\left(\xi_{2}, t_{2}\right) & \ldots & \tilde{T}\left(\xi_{2}, t_{K}\right) \\
\vdots & \vdots & \ddots & \vdots \\
\tilde{T}\left(\xi_{N}, t_{1}\right) & \tilde{T}\left(\xi_{N}, t_{2}\right) & \ldots & \tilde{T}\left(\xi_{N}, t_{K}\right)
\end{array}\right]
$$

Ці дані по суті є рядом полів просторових змінних, що складаються з $N$ точок, розрахованих для $K$ моментів часу, які містять у собі інформацію щодо динаміки досліджуваного об'єкту.

Розрахунок розподілених у просторі змінних, що визначають стан досліджуваного процесу, здійснюється за формулою (2). Змінні $T(\xi, t)$ виражаються у вигляді ряду ортонормованих базисних векторів (БВ) $\varphi_{i}(\xi)$ координати $\xi$, кожна з яких помножена на функцію часу $a_{i}(t)$ (коефіцієнти Фур' $\epsilon$ ).

Позначимо:

$$
\begin{gathered}
a(k):=\operatorname{col}\left\{a_{i}\left(t_{k}\right)\right\}_{i=1}^{N} \\
T(k):=\operatorname{col}\left\{\breve{T}\left(\xi_{l}, t_{k}\right)\right\}_{l=1}^{N} \\
\varphi_{i}:=\operatorname{col}\left\{\tilde{\varphi}_{i}\left(\xi_{l}\right)\right\}_{l=1}^{N} \quad \text { та } \Phi:=\left(\begin{array}{lllll}
\varphi_{1} & \varphi_{2} & \ldots & \varphi_{N}
\end{array}\right) .
\end{gathered}
$$

Із урахуванням цього рівняння (2) можна записати так:

$$
T(k)=\boldsymbol{\Phi} a(k)
$$

Оскільки стовпчики $\boldsymbol{\Phi}$ формують ортонормований базис, то матриця $\boldsymbol{\Phi} \epsilon$ ортогональною, що означає $\boldsymbol{\Phi}^{T} \boldsymbol{\Phi}=\mathbf{I}_{N}$, де $\mathbf{I}_{N}-$ одинична матриця $N \times N$.

Для побудови спрощеної моделі (2) потрібно визначити БВ та коефіцієнти Фур'є. БВ $\varphi_{i}(\xi)$ розраховуються із даних, що сформували матрицю (3). Після цього, рівняння моделі мають бути перетворені на залежність між керуванням u(t) і коефіцієнтами Фур'є $\left\{a_{i}(t)\right\}_{i=1}^{n}$. На цьому етапі застосовуються алгоритми системної ідентифікації [19]. У подальшому всі потрібні розрахунки були проведені, користуючись програмними пакетами Identification Toolbox, Simulink та програмними засобами Matlab [19].

Формування спрощеної математичної моделі

Згідно наведеної вище методики дослідження у результаті розрахунків за початковою складною математичною моделлю була сформована матриця (3), що містила інформацію про температуру в понад 125 тисячах просторових точках печі графітування протягом понад 350 моментів часу. Просторовий розподіл температур на момент часу графітування $\mathrm{h}=60$ год. показаний на рис.2.

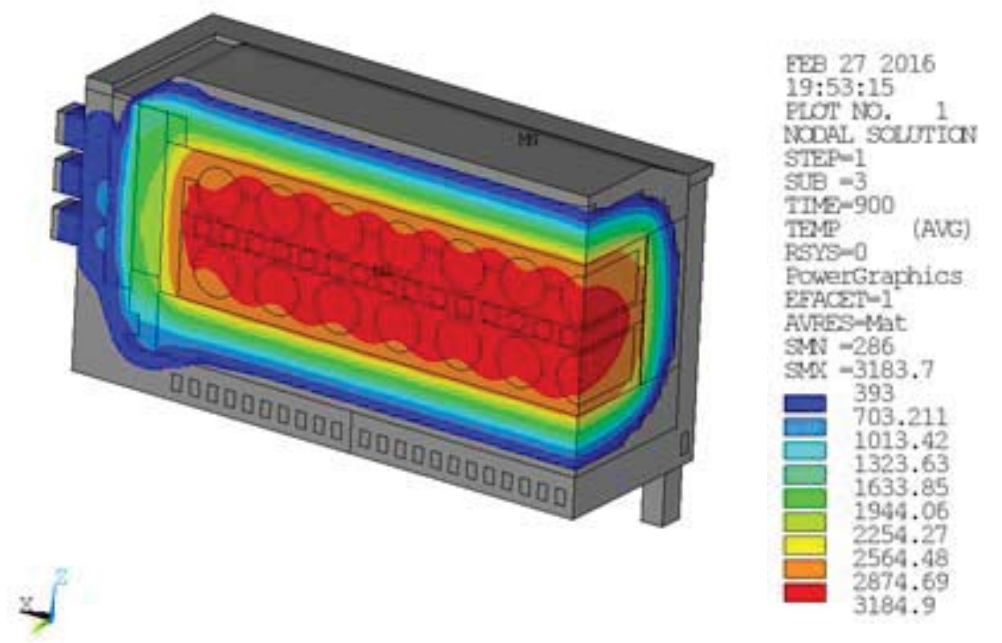

Рис. 2 - Розподіл температур у печі графітування на момент часу h = 60год. 
Розрахована матриця (3) містить біля півмільярда елементів. Зрозуміло, що обробляти матрицю такої вимірності достатньо складно. Тому 3 метою зменшення вимірності даної матриці, враховуючи високу інерційність печі графітування, була змінена дискретність вибірки у часі з 15 хвилин на 5 годин. Значення напруги електричного струму живлення, які діяли під час ординарної кампанії графітування, представлені у табл.1.

Для побудови спрощеної математичної моделі (2) процесу графітування потрібно визначити БВ $\varphi_{i}(\xi)$ та коефіцієнти Фур'є $a_{i}(t)$. БВ $\varphi_{i}$ визначаються за допомогою розкладу за сингулярними числами [20], а коефіцієнти Фур'є $a_{i}(t)$ з рівняння

$$
A=\left[\begin{array}{llll}
a(1) & a(2) & \ldots & a(K)
\end{array}\right]=\Phi^{\mathrm{T}} \mathrm{T},
$$

де $\boldsymbol{\Phi}$ - матриця, що складається з базис-векторів.

Матрицю базисних векторів Ф навести у табличному вигляді змоги немає, так як кількість ії елементів сягає декількох мільйонів. Натомість у табл.2 представлені коефіцієнти Фур'є.

Табл. 1 - Значення напруги струму живлення

\begin{tabular}{|c|c|c|c|c|c|}
\hline $\mathbf{0}$ годин & $\mathbf{5}$ годин & $\mathbf{1 0}$ годин & $\mathbf{1 5}$ годин & $\mathbf{2 0}$ годин & $\mathbf{2 5}$ годин \\
\hline 176,8570 & 181,7470 & 185,1820 & 175,8120 & 197,0490 & 201,0580 \\
\hline $\mathbf{3 0}$ годин & $\mathbf{3 5}$ годин & $\mathbf{4 0}$ годин & $\mathbf{4 5}$ годин & $\mathbf{5 0}$ годин & $\mathbf{5 5}$ годин \\
\hline 201,6850 & 190,4080 & 166,9580 & 159,4460 & 132,1880 & 108,5130 \\
\hline $\mathbf{6 0}$ годин & $\mathbf{6 5}$ годин & $\mathbf{7 0}$ годин & $\mathbf{7 5}$ годин & $\mathbf{8 0}$ годин & $\mathbf{8 5}$ годин \\
\hline 103,5510 & 103,1030 & 0 & 0 & 0 & 0 \\
\hline
\end{tabular}

Табл. 2 - Коефіцієнти Фур'є

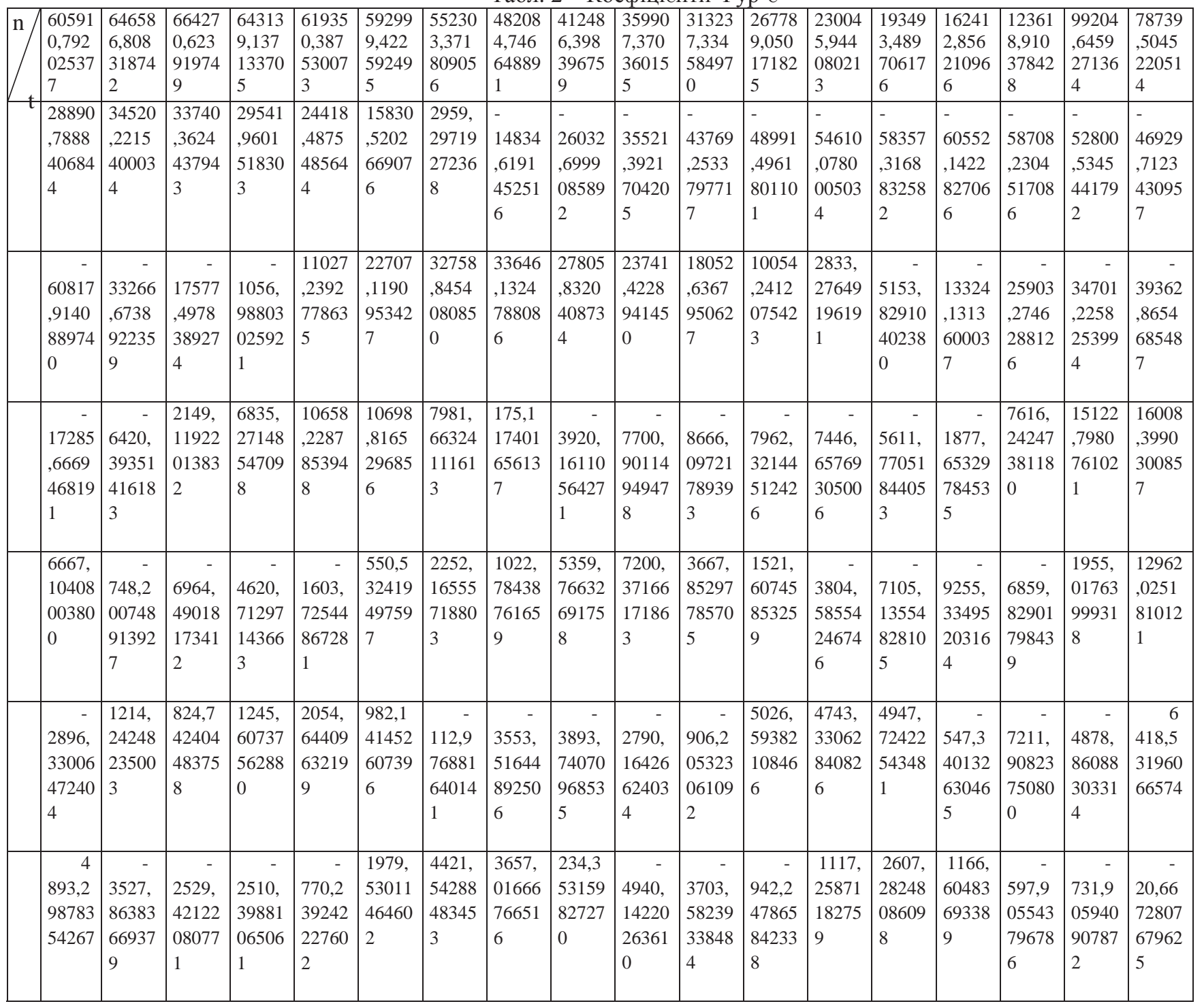



www.journal-atbp.com

\begin{tabular}{|c|c|c|c|c|c|c|c|c|c|c|c|c|c|c|c|c|c|c|}
\hline & \begin{tabular}{l}
\multicolumn{1}{r}{-} \\
697,3 \\
45824 \\
48436 \\
9
\end{tabular} & $\begin{array}{l}2100, \\
52298 \\
79304 \\
5\end{array}$ & $\begin{array}{l}\quad- \\
2106, \\
11422 \\
59241 \\
9\end{array}$ & $\begin{array}{l}50,59 \\
36582 \\
69907 \\
6\end{array}$ & $\begin{array}{l}662,2 \\
73788 \\
24285 \\
9\end{array}$ & $\begin{array}{l}374,4 \\
61785 \\
12803 \\
3\end{array}$ & $\begin{array}{l}\quad- \\
1089, \\
15484 \\
14665 \\
6\end{array}$ & $\begin{array}{l}164,8 \\
09597 \\
48796 \\
0\end{array}$ & $\begin{array}{l}2231, \\
56796 \\
86850 \\
5\end{array}$ & $\begin{array}{l}1766, \\
36506 \\
85783 \\
6\end{array}$ & $\begin{array}{l}\quad- \\
1899, \\
29511 \\
20028 \\
3\end{array}$ & $\begin{array}{l}\quad- \\
3007, \\
51342 \\
07816 \\
9\end{array}$ & $\begin{array}{l}\quad- \\
2665, \\
31616 \\
43172 \\
6\end{array}$ & $\begin{array}{l}1596, \\
24910 \\
84819 \\
7\end{array}$ & $\begin{array}{l}3634, \\
09859 \\
46366 \\
6\end{array}$ & $\begin{array}{l}893,4 \\
68431 \\
16668 \\
7\end{array}$ & \begin{tabular}{|l}
- \\
4234, \\
88426 \\
56721 \\
5
\end{tabular} & $\begin{array}{l}2394, \\
27712 \\
18395 \\
4\end{array}$ \\
\hline & $\begin{array}{l}718,0 \\
48987 \\
84528 \\
4\end{array}$ & $\begin{array}{l}573,3 \\
22747 \\
18988 \\
7\end{array}$ & $\begin{array}{l}- \\
3592, \\
17428 \\
21726 \\
9\end{array}$ & $\begin{array}{l}409,6 \\
45271 \\
29310 \\
2\end{array}$ & $\begin{array}{l}2246, \\
15910 \\
84810 \\
9\end{array}$ & $\begin{array}{l}1840, \\
94727 \\
11185 \\
1\end{array}$ & $\begin{array}{l}- \\
932,3 \\
04093 \\
68334 \\
9\end{array}$ & $\begin{array}{l} \\
1328, \\
62516 \\
20211 \\
2\end{array}$ & $\begin{array}{l} \\
818,5 \\
15109 \\
85731 \\
6\end{array}$ & $\begin{array}{l}- \\
169,3 \\
60981 \\
18606 \\
9\end{array}$ & $\begin{array}{l}725,8 \\
50864 \\
52258 \\
3\end{array}$ & $\begin{array}{l}- \\
55,62 \\
19963 \\
69261 \\
3\end{array}$ & $\begin{array}{l}1062, \\
01608 \\
28731 \\
8\end{array}$ & $\begin{array}{l}- \\
372,4 \\
14813 \\
88352 \\
1\end{array}$ & $\begin{array}{l}- \\
81,44 \\
40882 \\
16908 \\
5\end{array}$ & $\begin{array}{l}518,5 \\
06296 \\
49953 \\
3\end{array}$ & $\begin{array}{l}444,6 \\
62082 \\
89749 \\
3\end{array}$ & $\begin{array}{l}- \\
1163, \\
30424 \\
26141 \\
8\end{array}$ \\
\hline & $\begin{array}{l}1095, \\
46292 \\
09772 \\
1\end{array}$ & $\begin{array}{l}- \\
2550, \\
46590 \\
54976 \\
2\end{array}$ & $\begin{array}{l}556,6 \\
94585 \\
07131 \\
7\end{array}$ & $\begin{array}{l}719,7 \\
94102 \\
11189 \\
3\end{array}$ & $\begin{array}{l}849,1 \\
42939 \\
52594 \\
3\end{array}$ & $\begin{array}{l}- \\
18,35 \\
29501 \\
10518 \\
2\end{array}$ & $\begin{array}{l}- \\
157,7 \\
11271 \\
25466 \\
1\end{array}$ & $\begin{array}{l}- \\
411,1 \\
33937 \\
91661 \\
3\end{array}$ & $\begin{array}{l}- \\
1281, \\
59545 \\
77384 \\
9\end{array}$ & $\begin{array}{l}759,6 \\
86556 \\
31982 \\
4\end{array}$ & $\begin{array}{l}598,8 \\
97738 \\
66542 \\
7\end{array}$ & $\begin{array}{l}780,2 \\
67995 \\
70163 \\
6\end{array}$ & $\begin{array}{l}- \\
959,7 \\
84442 \\
61633 \\
1\end{array}$ & $\begin{array}{l}- \\
437,6 \\
32841 \\
05163 \\
5\end{array}$ & $\begin{array}{l}445,2 \\
46853 \\
23409 \\
7\end{array}$ & $\begin{array}{l}1027, \\
72233 \\
12428 \\
7\end{array}$ & \begin{tabular}{|l}
- \\
1464, \\
43789 \\
73128 \\
8
\end{tabular} & $\begin{array}{l}418,6 \\
69381 \\
38861 \\
8\end{array}$ \\
\hline 0 & $\begin{array}{l}266,5 \\
06511 \\
99931 \\
7\end{array}$ & $\begin{array}{l}- \\
995,9 \\
59841 \\
59334 \\
4\end{array}$ & $\begin{array}{l}- \\
214,9 \\
83980 \\
52124 \\
1\end{array}$ & $\begin{array}{l}1280, \\
64306 \\
04027 \\
5\end{array}$ & $\begin{array}{l}1193, \\
01179 \\
70653 \\
2\end{array}$ & $\begin{array}{l}- \\
1248, \\
99766 \\
48645 \\
5\end{array}$ & $\begin{array}{l}- \\
1427, \\
27856 \\
74575 \\
3\end{array}$ & $\begin{array}{l}630,4 \\
34860 \\
05947 \\
7\end{array}$ & $\begin{array}{l}1347, \\
35791 \\
79935 \\
1\end{array}$ & $\begin{array}{l}- \\
372,5 \\
93603 \\
53250 \\
3\end{array}$ & $\begin{array}{l}- \\
461,7 \\
95271 \\
04780 \\
5\end{array}$ & \begin{tabular}{|l}
- \\
16,72 \\
75436 \\
43539 \\
2
\end{tabular} & $\begin{array}{l} \\
132,2 \\
72565 \\
40142 \\
5\end{array}$ & $\begin{array}{l}657,9 \\
02233 \\
30357 \\
6\end{array}$ & $\begin{array}{l}- \\
191,3 \\
34312 \\
25268 \\
7\end{array}$ & \begin{tabular}{|l|} 
\\
940,8 \\
72121 \\
83867 \\
2
\end{tabular} & $\begin{array}{l}739,6 \\
33216 \\
94279 \\
9\end{array}$ & $\begin{array}{l}- \\
96,47 \\
63293 \\
95771 \\
4\end{array}$ \\
\hline
\end{tabular}

Для формування математичної моделі, яка зв'язує керування з коефіцієнтами Фур'є $\alpha_{i}(t)$, скористаємось моделлю авторегресії-ковзного середнього [21] $y(t)+a_{1} y(t-1)+\ldots+a_{n a} y(t-n a)=b_{1} u(t-n k)+\ldots+b_{n b} u(t-n b-n k+1)+e(t)$,

коефіцієнти якої $a_{1} \ldots a_{n a}$ обчислюються у результаті параметричної ідентифікації [22].

Структура спрощеної моделі, що розробляється, залежить від таких ії параметрів, як $n a, n b, n k$. Тому виникає потреба у проведенні дослідження, яка саме структура моделі $є$ кращою. При цьому якість моделі будемо оцінювати за середньоквадратичною похибкою апроксимації.

Зрозуміло, що поставлена задача не зовсім коректна у зв'язку з тим, що варіантів моделей існує нескінченна кількість. Тому обмежимося такими граничними значеннями параметрів: $n=18, n a, n b$ та $n k-5,19$ та 5 відповідно.

Дослідження точності спрощених математичних моделей

Нижче графічно представлені результати дослідження точності спрощених математичних моделей різних структур для чотирьох просторових точок, наведених вище.

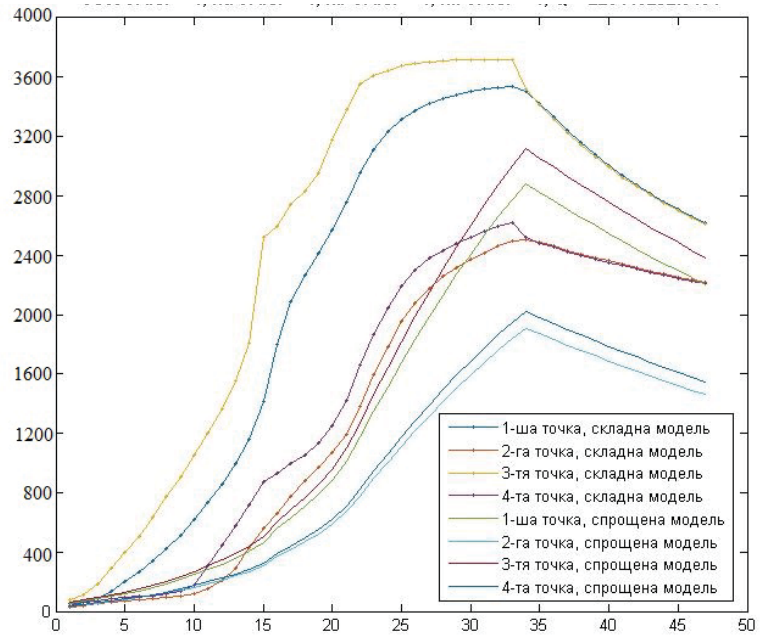

a)

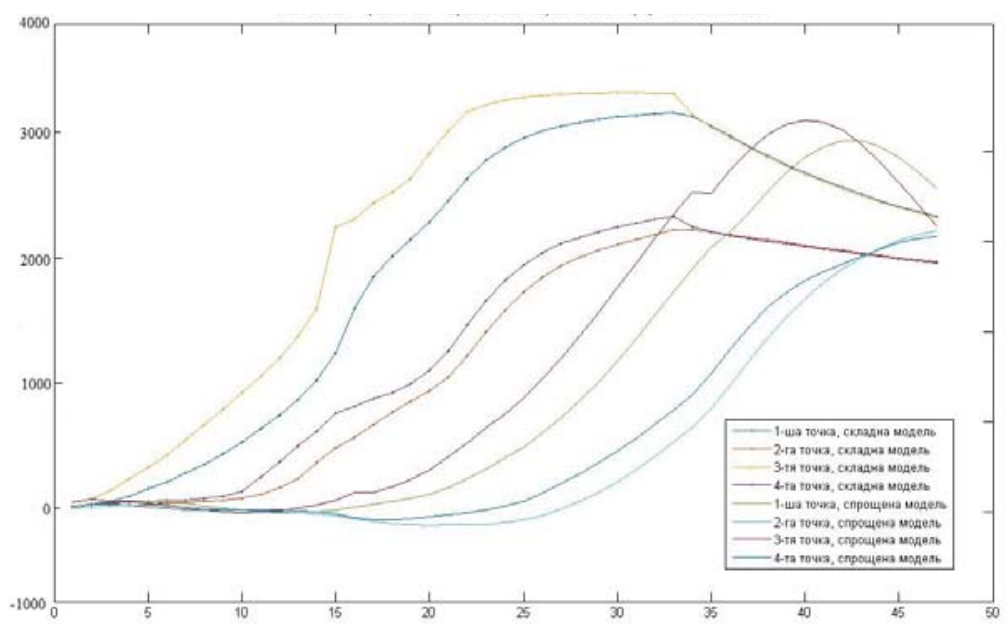

б)

Рис.3 - Значення температур у контрольних точках

a) $n-6, n a-1, n b-4, n k-1$, СКП- 256,3654

б) $n-6, n a-1, n b-5, n k-1$, СКП- 221,4880

Як видно з рис.3 у обох випадках спрощена модель не достатньо точно відтворює дані, отримані зі складної моделі, а тому вищенаведені структури не можуть використовуватися у подальших дослідженнях. 


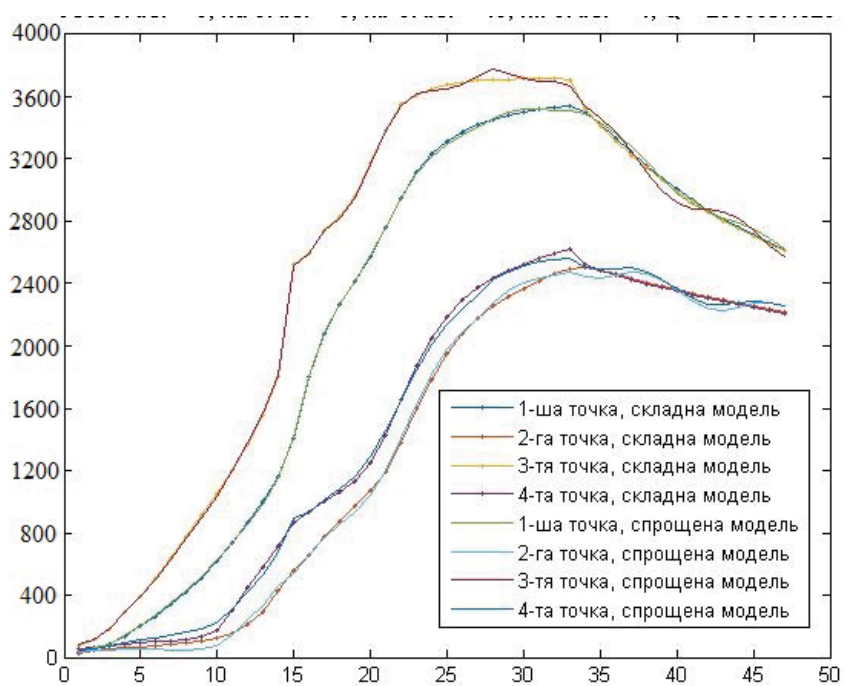

a)

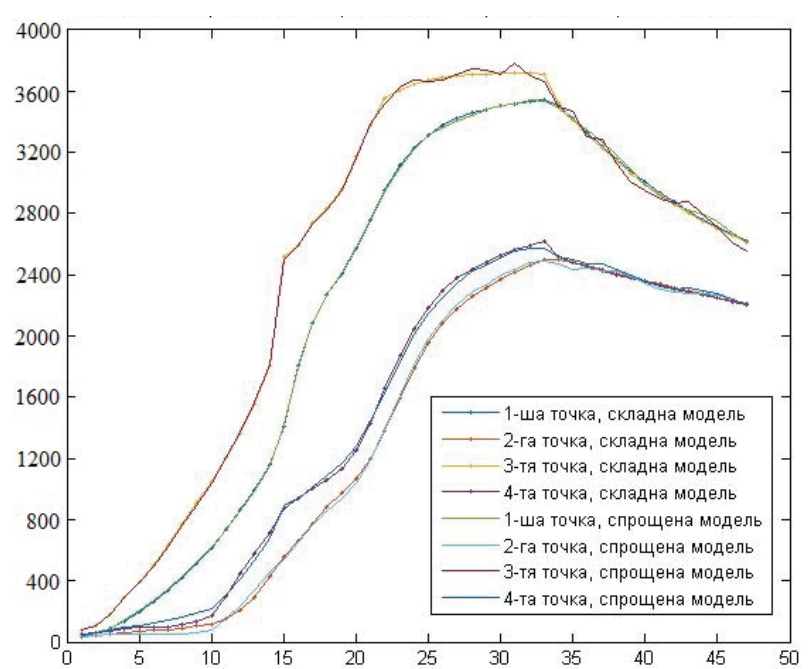

б)

Рис. 4 - Значення температур у контрольних точках

a) $n-7, n a-1, n b-2, n k-1$, СКП- 152,4117

б) $n-7, n a-1, n b-4, n k-1$, СКП- 122,3314

Графіки на рис.4 свідчать, що розглянуті структури спрощеної моделі досить непогано відтворюють значення температур у контрольних точках та все ж значення критерію якості залишається досить великим.

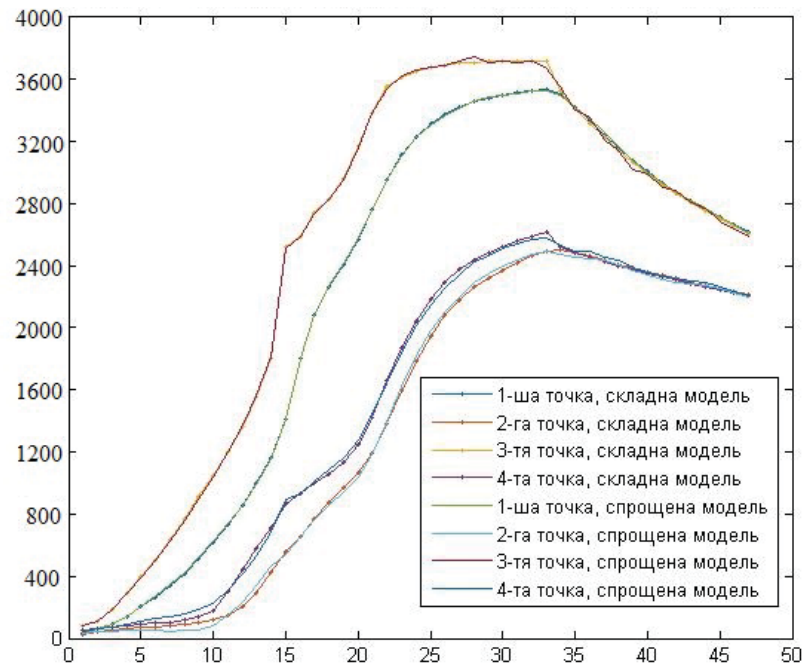

a)

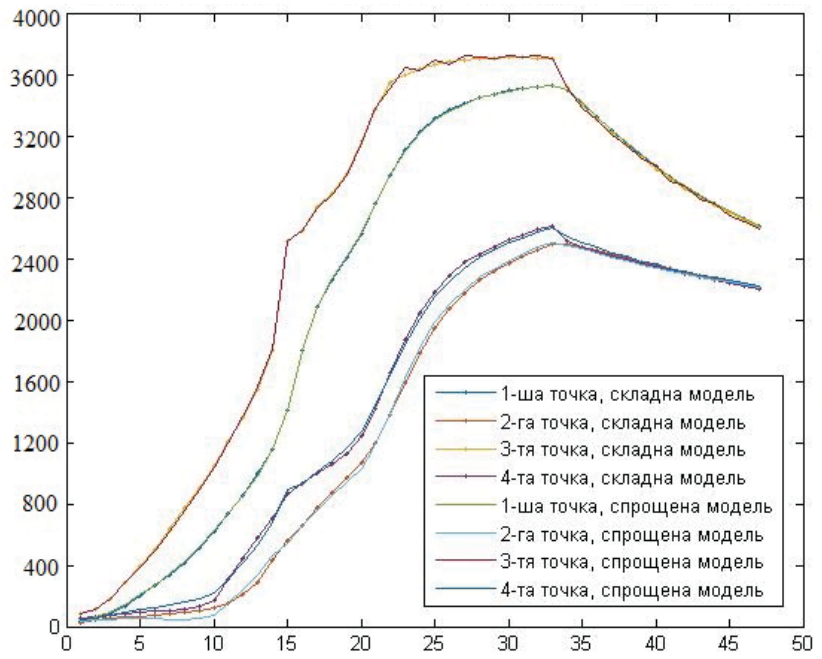

б)

Рис.5 - Значення температур у контрольних точках:

a) $n-7, n a-2, n b-2, n k-1$, СКП- 108,5160

б) $n-11, n a-1, n b-2, n k-1$, СКП- 79,7619

Ще кращі результати щодо точності забезпечують спрощені моделі зі структурами, результати дослідження яких представлені на рис.5. У табл.3 наведено конфігурації десяти моделей, що мали найменшу похибку апроксимації.

Табл. 3 - Середньоквадратичні похибки апроксимації

\begin{tabular}{|c|c|c|c|c|}
\hline$n$ & $n a$ & $n b$ & $n k$ & $\begin{array}{c}\text { Середньоквадратична } \\
\text { похибка }\end{array}$ \\
\hline 11 & 1 & 2 & 1 & 79,7619 \\
\hline 7 & 2 & 1 & 1 & 108,5160 \\
\hline 7 & 1 & 4 & 1 & 122,3314 \\
\hline 10 & 1 & 2 & 1 & 152,4117 \\
\hline 7 & 1 & 5 & 1 & 160,5837 \\
\hline
\end{tabular}



www.journal-atbp.com

\begin{tabular}{|c|c|c|c|c|}
\hline 11 & 1 & 3 & 1 & 182,9811 \\
\hline 12 & 1 & 2 & 1 & 190,7143 \\
\hline 9 & 1 & 2 & 1 & 207,7594 \\
\hline 6 & 1 & 5 & 1 & 221,4880 \\
\hline 6 & 1 & 4 & 1 & 256,3654 \\
\hline
\end{tabular}

Як видно із табл.2, практично відсутня будь-яка детермінована залежність між параметрами спрощеної моделі та точністю відтворення нею експериментальних даних. Найточнішою виявилась модель 3 параметрами n=11 та na, nb та nk - 1, 2 та 1 відповідно. Саме цю модель і будемо використовувати у подальших дослідженнях.

\section{Висновки}

У даній статті розв'язана задача побудови спрощеної математичної моделі процесу графітування вуглецевих виробів, яка відрізняється від відомих моделей практично нульовим часом іiі розрахунку. Проведене дослідження альтернативних спрощених моделей дозволило вибрати модель оптимальної структури, яка по точності у достатній мірі наближена до початкової складної математичної моделі.

Побудована спрощена математична модель надає можливість підвищити ефективність дослідження температурного режиму процесу графітування вуглецевих виробів за рахунок скорочення часу дослідження, визначати температури у будь-якій точці процесу, навіть там, де немає вимірювальних пристроїв. Дана модель може бути використана для синтезу системи керування процесом, а також у складі системи керування реального часу.

Усі названі вище питання і становлять предмет подальших досліджень.

\section{Література}

[1] Aris, Rutherford (1994). Mathematical Modelling Techniques, New York: Dover. ISBN 0-486-68131-9

[2] Bender, E.A. (2000). An Introduction to Mathematical Modeling, New York: Dover. ISBN 0-486-41180-X

[3] Шевяков А. А. Управление тепловыми объектами с распределенными параметрами / А. А. Шевяков, Р. В. Яковлева. - Москва: Энергоатомиздат, 1986. - 208 с.

[4] Производство электродной продукции / [А. К. Санников, А. Б. Сомов, В.В.Ключников и др.]. - М. : Металлургия, 1985. - 129 с.

[5] Чалых Е. Ф. Технология и оборудование электродных и электроугольных предприятий / Е. Ф. Чалых. - М. : Металлургия, 1972. - 432 с.

[6] Кузнецов Д. М. Процесс графитации углеродных материалов. Современные методы исследования : монография / Д. М. Кузнецов, В. П. Фокин. - Новочеркасск : ЮРГТУ, 2001. - 132 с.

[7] Physical processes modern investigation methods in power-intensive industrial equipments / E. N. Panov, A. Ya. Karvatsky, I. L. Shilovich [et al.] // Aluminium of Siberia - 2008 : XIV Intern. conf. exhib., (Krasnoyarsk, Sept. 10—12, 2008) : proceedings of the conf. — Krasnoyarsk : «Verso», 2008. — P. 124-132.

[8] Девятов Б. Н. Теория и методы анализа управляемых распределенных процессов / Б. Н. Девятов, Н. Д. Демиденко. - Новосибирск: Наука, 1983. - 271 с.

[9] Бутковский А. Г. Теория оптимального управления системы с распределенными параметрами / А. Г. Бутковский. Москва: Наука, 1965. - 474 с.

[10] Васильева А. Б. Асимптотические методы в теории сингулярных возмущений / А. Б. Васильева, В. Ф. Бутузов. Москва: Высшая школа, 1990. - 208 с.

[11] Маковский В. А. Динамика металлургических объектов с распределенными параметрами / В. А. Маковский. Москва: Металлургия, 1971. - 384 с.

[12] Рей У. Методы управления технологическими процессами / У. Рей. - Москва: Мир, 1983. - 368 с.

[13] Чермак И. Динамика регулируемых систем в теплоэнергетике и химии / И. Чермак, В. Паперка, И. Заворка. Москва: Мир, 1972. - 623 с.

[14] Шевяков А. А. Инженерные методы расчета динамики теплообменных аппаратов / А. А. Шевяков, Р. В. Яковлева. - Москва: Машиностроение, 1968. - 314 с.

[15] Рапопорт Э. Я. Структурное моделирование объектов и систем управления с распределенными параметрами / Э. Я. Рапопорт. - Москва: Высшая школа, 2003. - 239 с.

[16] Лелека, С. В. Теплоэлектрическое состояние печей графитирования Ачесона [Текст]: монография / С. В. Лелека, Е. Н. Панов, А. Я. Карвацкий и др. - К.: НТУУ «КПИ», 2014. - 238 с

[17] Панов, Е. Н. Энергосбережение при производстве электродной продукции [Текст]: 3-й междунар. конгр./ Е. Н. Панов, С. В. Кутузов, А. Я. Карвацкий и др. // Цветные металлы. - Красноярск, 2011.

[18] Жученко О.А. Метод спрощення математичних моделей об'єктів керування із розподіленими параметрами / О. А. Жученко, В. С. Цапар // Міжнародний науково-виробничий журнал «Автоматизація технологічних і бізнеспроцесів» Vol. 7, issue 1/2015. C. 15-25.

[19] Gilat, Amos (2004). MATLAB: An Introduction with Applications 2nd Edition. John Wiley \& Sons. ISBN 978-0-47169420-5. 
[20] П.І. Бідюк, О.С. Меняйленко, О.В. Половцев. Методи прогнозування. - Луганськ: Альма-матер, 2008,308 стр.

[21] Box George E. P., Jenkins Gwilym M. Time series analysis, forecasting and control. Holden-day, Inc., 1976.

[22] Эйкхофф П. Основы идентификации систем управления: оценива- ние параметров и состояния / Эйкхофф П. - М. : Мир, 1975. - 683 с.

\section{References}

[1] Aris, Rutherford (1994). Mathematical Modelling Techniques, New York: Dover. ISBN 0-486-68131-9

[2] Bender, E.A. (2000). An Introduction to Mathematical Modeling, New York: Dover. ISBN 0-486-41180-X

[3] Shevyakov A. A. Upravlenye teplovymy obektamy s raspredelennymy parametramy / A. A. Shevyakov, R. V. Yakovleva. - Moskva: Enerhoatomyzdat, 1986. - 208 s.

[4] Proyzvodstvo elektrodnoy produktsyy / [A. K. Sannykov, A. B. Somov, V. V. Klyuchnykov y dr.]. - M. : Metallurhyya, 1985. - $129 \mathrm{~s}$.

[5] Chalykh E. F. Tekhnolohyya y oborudovanye elektrodnykh i elektrouhol'nykh predpryyatyy / E. F. Chalykh. - M. : Metallurhyya, 1972. - $432 \mathrm{~s}$.

[6] Kuznetsov D. M. Protsess hrafytatsyy uhlerodnykh materyalov. Sovremennye metodi yssledovanyya : monohrafyya / D. M. Kuznetsov, V. P. Fokyn. — Novocherkassk : YuRHTU, 2001. — 132 s.

[7] Physical processes modern investigation methods in power-intensive industrial equipments / E. N. Panov, A. Ya. Karvatsky, I. L. Shilovich [et al.] // Aluminium of Siberia - 2008 : XIV Intern. conf. exhib., (Krasnoyarsk, Sept. 10—12, 2008) : proceedings of the conf. — Krasnoyarsk : «Verso», 2008. — P. 124-132.

[8] Devyatov B. N. Teoryya y metodi analyza upravlyaemikh raspredelennikh protsessov / B. N. Devyatov, N. D. Demydenko. - Novosybyrsk: Nauka, 1983. - 271 s.

[9] Butkovskyy A. H. Teoryya optymal'noho upravlenyya systemi s raspredelennibmy parametramy / A. H. Butkovskyy. Moskva: Nauka, 1965. - 474 s.

[10] Vasyl'eva A. B. Asymptotycheskye metodi v teoryy synhulyarnikh vozmushchenyy / A. B. Vasyl'eva, V. F. Butuzov. Moskva: Vыsshaya shkola, 1990. - 208 s.

[11] Makovskyy V. A. Dynamyka metallurhycheskykh obektov s raspredelennimy parametramy / V. A. Makovskyy. Moskva: Metallurhyya, 1971. - 384 s.

[12] Rey U. Metodi upravlenyya tekhnolohycheskymy protsessamy / U. Rey. - Moskva: Myr, 1983. - 368 s.

[13] Chermak Y. Dynamyka rehulyruemikh system v teploenerhetyke y khymyy / Y. Chermak, V. Paperka, Y. Zavorka. Moskva: Myr, 1972. - 623 s.

[14] Shevyakov A. A. Ynzhenernie metodi rascheta dynamyky teploobmennikh apparatov / A. A. Shevyakov, R. V. Yakovleva. - Moskva: Mashynostroenye, 1968. - 314 s.

[15] Rapoport Э. Ya. Strukturnoe modelyrovanye obektov y system upravlenyya s raspredelennimy parametramy / Э. Ya. Rapoport. - Moskva: Visshaya shkola, 2003. - 239 s.

[16] Leleka, S. V. Teploelektrycheskoe sostoyanye pechey hrafytyrovanyya Achesona [Tekst]: monohrafyya / S. V. Leleka, E. N. Panov, A. Ya. Karvatskyy y dr. - K.: NTUU «KPY», 2014. - 238 s

[17] Panov, E. N. Enerhosberezhenye pry proyzvodstve elektrodnoy produktsyy [Tekst]: 3-y mezhdunar. konhr./ E. N. Panov, S. V. Kutuzov, A. Ya. Karvatskyy y dr. // Tsvetnie metalli. - Krasnoyarsk, 2011.

[18] Zhuchenko O.A. Metod sproshchennya matematychnykh modeley ob"yektiv keruvannya iz rozpodilenymy parametramy / O. A. Zhuchenko, V. S. Tsapar // Mizhnarodnyy naukovo-vyrobnychyy zhurnal «Avtomatyzatsiya tekhnolohichnykh i biznes-protsesiv» Vol. 7, issue 1/2015. S. 15-25.

[19] Gilat, Amos (2004). MATLAB: An Introduction with Applications 2nd Edition. John Wiley \& Sons. ISBN 978-0-47169420-5.

[20] P.I. Bidyuk, O.S. Menyaylenko, O.V. Polovtsev. Metody prohnozuvannya. - Luhans'k: Al'ma-mater, 2008,308 str.

[21] Box George E. R., Jenkins Gwilym M. Time series analysis, forecasting and control. Holden-day, Inc., 1976.

[22] Eykkhoff P. Osnovi identyfykatsyy system upravlenyya: otsenyva nye parametrov i sostoyanyya / Eykkhoff P. - M. : Myr, 1975. - $683 \mathrm{~s}$. 